\title{
PENENTUAN WAKTU BAKU PRODUKSI KERUPUK RAMBAK IKAN LAUT "SARI ENAK" DI SUKOHARJO
}

\author{
Darsini \\ Program Studi Teknik Industri Fakultas Teknik \\ Universitas Veteran Bangun Nusantara Sukoharjo \\ E-mail : dearsiny@yahoo.com
}

\begin{abstract}
ABSTRAK
Tujuan dalam penelitian ini adalah untuk mengetahui waktu baku dalam proses produksi rambak/kerupuk ikan laut di KUBE “Sari Enak” yang beralamat di Wotgaled RT2 RW IX Sukoharjo. Obyek penelitian adalah pada proses produksi pembuatan kerupuk rambak ikan laut. Metode yang digunakan dalam pengumpulan data dengan cara observasi langsung di lapangan dan teknik pengukuran waktu kerja dengan menggunakan metode pengukuran jam henti. Metode pengolahan data dengan uji keseragaman data dan uji kecukupan data, kemudian dilakukan penghitungan waktu normal dan waktu baku (standart) dalam proses produksi. Dari hasil pengolahan dan pembahasan diperoleh bahwa data yang telah diperoleh selama 20 kali pengamatan yang terdiri dari 6 stasiun kerja menunjukkan data seragam dan telah cukup. Sedangkan waktu baku yang digunakan untuk proses produksi dalam pembuatan kerupuk rambak ikan laut dalam 1 periode pembuatan $(60 \mathrm{~kg})$ membutuhkan waktu 306.58 menit, dalam satu hari dapat memproduksi kerupuk ikan laut sebanyak 1 sampai 2 kali produksi.
\end{abstract}

Kata Kunci : Waktu baku, proses produksi rambak ikan laut.

\section{PENDAHULUAN}

Kelurahan Sukoharjo merupakan salah satu kelurahan di pusat kota kabupaten Sukoharjo namun pencaharian penduduknya masih ada yang buruh tani mencapai 1.485 orang, dan lain-lain mencapai 1.883 orang termasuk industri kecil yang bergerak di bidang produksi makanan kecil. Salah satu industri kecil tersebut telah membentuk kelompok usaha bersama (Kube) yang disebut KUBE "Sari Enak” yang saat ini masih berkategori Kube tumbuh. KUBE yang diberi nama "Sari Enak" yang memproduksi makanan olahan dari kulit ikan laut "menjadi kerupuk rambak. Rambak adalah makanan semacam krupuk atau kripik yang biasanya diolah dari kulit sapi, kerbau atau kambing. Rambak biasanya dikonsumsi sebagai makanan kecil atau pendamping makan nasi. Kerupuk rambak yang diproduksi KUBE "Sari Enak" diberi label Rambak Asli Ikan Laut " SARI ENAK” dan telah dilakukan uji keamanan di Dinas Kesehatan Sukoharjo dan dinyatakan aman dikonsumsi sehingga telah memiliki sertifikat tertanggal 04 Juni 2008 dengan kategori Produksi Pangan Industri Rumah Tangga (P-IRT) No. 20233101188.

Kelompok usaha bersama (KUBE) "Sari Enak” ini dirintis oleh Bapak Sri Yatno sejak 4 tahun lalu. Dalam perkembangan usaha yang terus dijalankannya, makin lama menunjukkan geliat hasilnya kemudian terbentuklah kelompok-kelompok yang mendukung usaha ini yang hingga saat ini dipakailah sistem inti plasma. Sebagai inti adalah usaha pengolahan kulit ikan laut yang dikelola oleh Bapak Sri Yatno sedang plasma adalah kelompok-kelompok yang melakukan pengemasan terhadap produk jadi berupa kerupuk rambak kulit ikan laut. Saat ini produksi kerupuk rambak yang dijalankan oleh KUBE "Sari Enak" hanya mencapai $50 \mathrm{~kg}$ bahan baku per 2 minggu. Padahal sebenarnya kapasitas produksi bisa jauh lebih tinggi. Dari hasil pengamatan diketahui bahwa mulai dari proses pengukusan, pencampuran bumbu, penjemuran, penggorengan dan pengemasan semua dilakukan dengan cara manual. Meskipun dengan cara manual selain pencampuran bumbu semua tahapan proses tidak terdapat kendala yang berarti. Untuk pemasaran krupuk ikan 
laut di wilayah sekitar kabupaten Sukoharjo seperti kabupaten Sragen, kabupaten Karanganyar.

Untuk mengetahui waktu, kuantitas, kualitas, serta biaya produksi harus diketahui waktu baku yang digunakan untuk proses produksi dalam pembuatan kerupuk rampak ikan laut tersebut. Untuk itu perlu dilakukan perhitungan analisis waktu baku sehinga dapat diketahui waktu yang diperlukan dalam proses produksi tersebut. Berikut gambar proses pembuatan kerupuk rambak ikan laut.

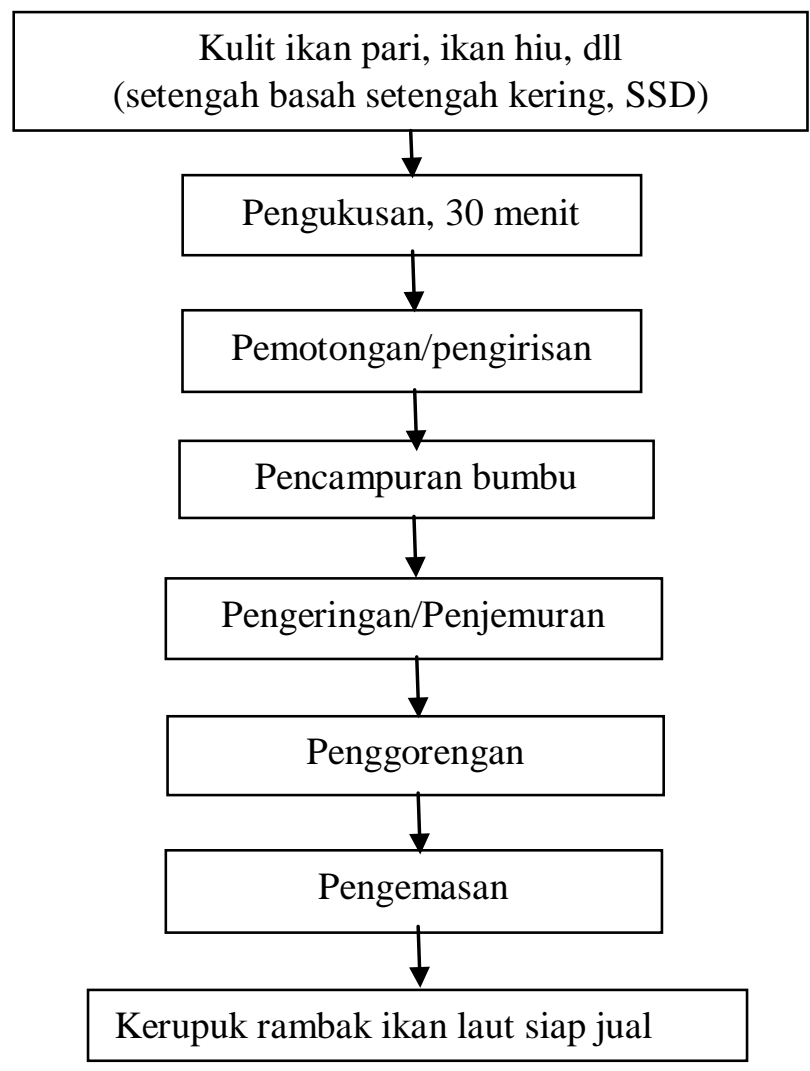

Gambar 1. Proses pembuatan kerupuk rambak ikan laut

Berdasarkan proses produksi tersebut akan di lakukan penghitungan waktu baku dalam proses pembuatan krupuk rambak ikan laut tersebut di atas, sehingga dapat memberikan masukan yang berhubungan dengan kegiatan produksi terhadap KUBE "Sari Enak" di Wotgaleh Sukoharjo.

\section{LANDASAN TEORI}

\section{A. Pengertian Pengukuran Waktu Kerja}

Pengukuran waktu kerja dan analisis metode kerja pada dasarnya memusatkan pada bagaimana pekerjaan tersebut diselesaikan. Pengukuran waktu kerja adalah pekerjaan mengamati perkerja dan mencatat waktu kerjanya baik tiap elemen maupun siklus. Tujuan dari pengukuran waktu kerja adalah untuk menentukan waktu kerja rata-rata yang dibutuhkan oleh operator dalam melakukan suatu pekerjaan. Tujuannya untuk mendapatkan waktu baku penyelesaian pekerjaan, yakni waktu yang secara wajar untuk menyelesaikan suatu pekerjaan yang dilaksanakan dalam system kerja terbaik. Pengukuran waktu kerja dapat dilakukan secara langsung, yaitu suatu bentuk atau cara pengukuran kerja yang dilakukan di tempat dimana pekerjaan tersebut dijalankan. Ada dua cara yang termasuk di dalam 
pengukuran secara langsung, yaitu pengukuran dengan cara jam henti (Stop Watch) dan sampling pekerjaan (Wignyosoebroto, 1989).

Pengukuran waktu ditujukan juga untuk mendapatkan waktu baku penyelesaian dalam proses produksi, yaitu yang dibutuhkan secara wajar oleh seorang pekerja normal untuk menyelesaikan pekerjaan yang dijalankan dalam system kerja yang terbaik (Sutalaksana, 1980 : 117)

\section{B. Pengukuran Waktu Kerja dengan Jam Henti}

Pengukuran waktu jam henti adalah perangkat pengukuran yang telah digunakan secara luas dalam industry. Sesuai dengan namanya, teknik ini menggunakan jam henti sebagai alat pengukur waktu. Cara ini paling dikenal, karena aturan-aturan cara penggunaannya sangat sederhana (Assauri Sofyan, 1984).

Secara garis besar langkah-langkah untuk pelaksanaan pengukuran waktu kerja dengan jam henti adalah sebagai berikut :

a. Definisikan pekerjaan yang akan diteliti untuk diukur waktunya dan beritahukan maksud dan tujuan pengukuran ini kepada pekerja yang dipilih untuk diamati dan supervisor.

b. Catat informasi yang berkaitan erat dengan penyelesaian pekerjaan seperti layout, spesifikasi mesin atau peralatan kerja yang digunakan dan lain-lain.

c. Bagi operasi kerja sedetail-detailnya tetapi masih dalam kemudahan untuk pengukuran waktu.

d. Amati, ukur dan catat waktu yang dibutuhkan oleh operator untuk menyelesaikan elemen-elemen kerja tersebut.

e. Terapkan siklus kerja yang harus diukur dan dicatat, tes pula keseragaman dana dan kecukupan data.

f. Tetapkan rata of performance dari operatos saat melaksanakan ektifitas kerja yang diukur dan dicatat waktu tersebut.

g. Sesuaikan waktu pengamatan dan performance kerja yang ditujukan oleh operator tersebut sehingga akhirnya akan diperoleh waktu kerja normal.

h. Ditetapkan waktu longgar (allowance time) guna menghadapi kondisi-kondisi seperti kebutuhan pribadi, factor kelelahan, keterlambatan material, dan lain-lain.

i. Tetapkan waktu baku yaitu jumlah dari waktu normal dan waktu longgar. Untuk menentukan waktu baku dengan rumus : (Wignyosoebroto, 1989)

$$
W b=W n \times \frac{100 \%}{100 \%-\text { Allowance }}
$$

Dimana :

$\mathrm{Wb}=$ Waktu baku

Wn $=$ Waktu normal

$\mathrm{L} \quad=$ Faktor Kelonggaran

\section{Uji Keseragaman Data}

Berdasarkan langkah-langkah tersebut terlihat bahwa pengukuran kerja dengan jam henti ini merupakan pengukuran yang obyektif karena disini waktu yang ditetapkan berdasarkan fakta yang terjadi dan tidak sekedar diestimasi secara obyektif.

Data yang diperoleh dari pengukuran terlebih dahulu dilakukan uji keseragaman data sebelum digunakan untuk menetapkan waktu baku. Uji keseragaman data dilaksanakan dengan mengaplikasikan peta control (control chart) adalah suatu alat yang cocok untuk menguji keseragaman data yang diperoleh dari pengamatan. Data yang diperoleh dari pengukuran dikelompokkan ke dalam sub group-sub group (Wignyosoebroto, 1989). 
Uji keseragaman data dilakukan dengan langkah-langkah sebagai berikut :

1. Memasukkan data ke dalam sub group dan menghitung rata-rata dari setiap sub group dengan rumus sebagai berikut :

$$
X=\frac{\mathrm{zX}}{\mathrm{n}}
$$

Dimana :

$\mathrm{X}=$ Rata-rata dari seluruh sub group

$\mathrm{X}_{1} \quad=$ Waktu penyelesaian yang diamati

$\mathrm{n} \quad=$ Banyaknya data dari sub group ke-i

2. Menghitung harga rata-rata dari harga ratasub group

Dimana :

$$
X=\frac{\mathrm{zX}}{\mathrm{n}}
$$

$$
\begin{array}{ll}
\mathrm{X} & =\text { Rata-rata dari seluruh sub group } \\
\mathrm{X} & =\text { Rata-rata dari sub group } \\
\mathrm{k} \sigma & =\text { Banyaknya sub group }
\end{array}
$$

3. Menghitung harga standar deviasi sebenarnya dari waktu penyelesaian dengan rumus sebagai berikut :

Dimana :

$$
\sigma=\sqrt{\frac{\sum(X i-\overline{\bar{X}})^{2}}{(N-1)}}
$$

$\mathrm{N} \quad$ = Jumlah pengamatan pendahulu yang sudah dilakukan

$\mathrm{X}_{1} \quad=$ Data waktu pengamatan

4. Menghitung deviasi dari distribusi harga sub group dengan rumus sebagai berikut :

Dimana :

$$
\sigma X=\frac{\sigma}{\sqrt{n}}
$$

$\sigma \quad=$ Standar deviasi sebenarnya

$\mathrm{n} \quad=$ Banyaknya data setiap group/ukuran sub group

$\sigma \mathrm{X}=$ Standar deviasi dari distribusi rata-rata sub group

5. Menghitung batas control atas dan batas control bawah dengan rumus sebagai berikut :

$\mathrm{K}=$ Jarak batas pengendali dari garis tengah

$$
\begin{aligned}
\mathrm{BKA} & =\mathrm{X}+\mathrm{k} \cdot \sigma . \mathrm{X} \\
\mathrm{BKB} & =\mathrm{X}-\mathrm{k} \cdot \sigma . \mathrm{X}
\end{aligned}
$$

Dimana :

$$
\text { - } \quad \text { Tingkat kepercayaan 68\% maka nilai } \mathrm{k}=1
$$

- $\quad$ Tingkat kepercayaan 95\% maka nilai $\mathrm{k}=2$

- $\quad$ Tingkat kepercayaan 99\% maka nilai $\mathrm{k}=3$

Data yang berada di luar batas kontrol atas dan batas kontrol bawah data tersebut adalah data ekstrim dan harus dibuang (Wignyosoebroto, 1989).

\section{Uji Kecukupan Data}

Pengujian ini dilakukan untuk mengetahui apakah sampel data yang telah diambil cukup mewakili atau populasi atau belum. Yang ideal adalah dengan melakukan pengukuran / pengamatan yang jumlahnya cukup banyak. Namun hal tersebut tidak mungkin mengingat factor waktu, tenaga, dan biaya.

Untuk menetapkan berapa jumlah pengamatan yang seharusnya dilakukan di sini diputuskan dahulu tingkat keyakinan (confidence of accurancy) untuk mengukuran ini yang merupakan tingkat kepastian yang diinginkan oleh pengamat / 
analis berkenaan dengan pengamatan yang dilakukan tersebut. Di dalam aktifitas pengukuran kerja biasanya diambil 95\% tingkat keyakinan, dan 5\% derajat ketelitian. Hal ini berarti bahwa sekurang-kurangnya 95 dari 100 rata-rata dari waktu dicatat / diukur untuk suatu elemen kerja akan memiliki penyimpangan lebih dari 5\% dengan demikian formula yang digunakan sebagai berikut: (Sutalaksana, 1980)

$$
N^{\prime}=\left[\frac{k / s \sqrt{N \sum X^{2}-\left(\sum X\right)^{2}}}{\sum X}\right]^{2}
$$

Dimana :

$\mathrm{N}^{`} \quad=$ keseragaman dan kecukupan data

$\mathrm{N} \quad=$ banyak data yang diukur

$\mathrm{k} \quad=$ tingkat kepercayaan

$\mathrm{s} \quad=$ derajat ketelitian

Dari langkah uji keseragaman data data dan kecukupan data akan didapat harga $\mathrm{N}^{`}$ sehingga dapat diambil kesimpulan sebagai berikut :

- $\mathrm{N}^{`} \leq \mathrm{N}$ maka data yang telah diambil sudah cukup dan tidak perlu melakukan pengambilan data kembali.

$-\mathrm{N}^{`} \geq \mathrm{N}$ maka data belum cukup dan harus melakukan pengambilan data tambahan sebanyak $\mathrm{N} `^{\prime} \mathrm{N}$ data

Dalam penelitian ini penulis mengambil tingkat kepercayaan 95\% (k-2) dan derajat ketelitian 5\% (s-0,05)

\section{METODE PENELITIAN}

Obyek penelitian adalah pada proses produksi pembuatan kerupuk rambak ikan laut. Sedangkan tempat penelitian dilaksanakan di KUBE “Sari Enak” yang Dukuh Wotgaleh RT 02 RW IX Kalurahan Sukoharjo, Kecamatan/Kabupaten Sukoharjo.

Metode yang digunakan untuk mendukung dalam penelitian ini diperoleh melalui metode pengumpulan data sebagai berikut :

1. Observasi melalui dokumen perusahaan, dengan mengajukan pertanyaanpertanyaan secara langsung kepada pemilik KUBE untuk mendapatkan data-data yang diperlukan seperti : sejarah KUBE “Sari Enak”, jumlah tenaga kerja, jam kerja/hari, jam kerja per hari/jumlah produksi dan kondisi lingkungan kerja.

2. Observasi lapangan, dengan melakukan pengamatan dan pencatatan secara langsung terhadap obyek yang akan diteliti yaitu proses produksi pembuatan kerupuk ikan laut.

3. Teknik pengukuran waktu kerja pada proses produksi dengan menggunakan metode pengukuran jam henti. Data-data yang diukur meliputi : (1) Jam kerja operator tiap elemen pekerjaan, (2) Penilaian lingkungan kerja untuk menentukan besar kelonggaran, dan (3) Penilaian cara dan sikap kerja untuk menentukan performance rating factor.

Sedangkan untuk metode pengolahan data dilakukan dengan :

1. Pengukuran waktu kerja dilakulam secara langsung dengan menggunakan jam henti (stop watch)

2. Pengujian keseragaman data dan kecukupan data
a. Menghitung harga rata-rata
b. Menghitung standar deviasi
c. Menghitung keseragaman data
d. Menghitung kecukupan data

3. Menghitung waktu baku / waktu standar

a. Menghitung waktu normal

b. Menghitung waktu baku 

berikut :

Adapun langkah-langkah atau kerangka pemecahan masalahnya adalah sebagai

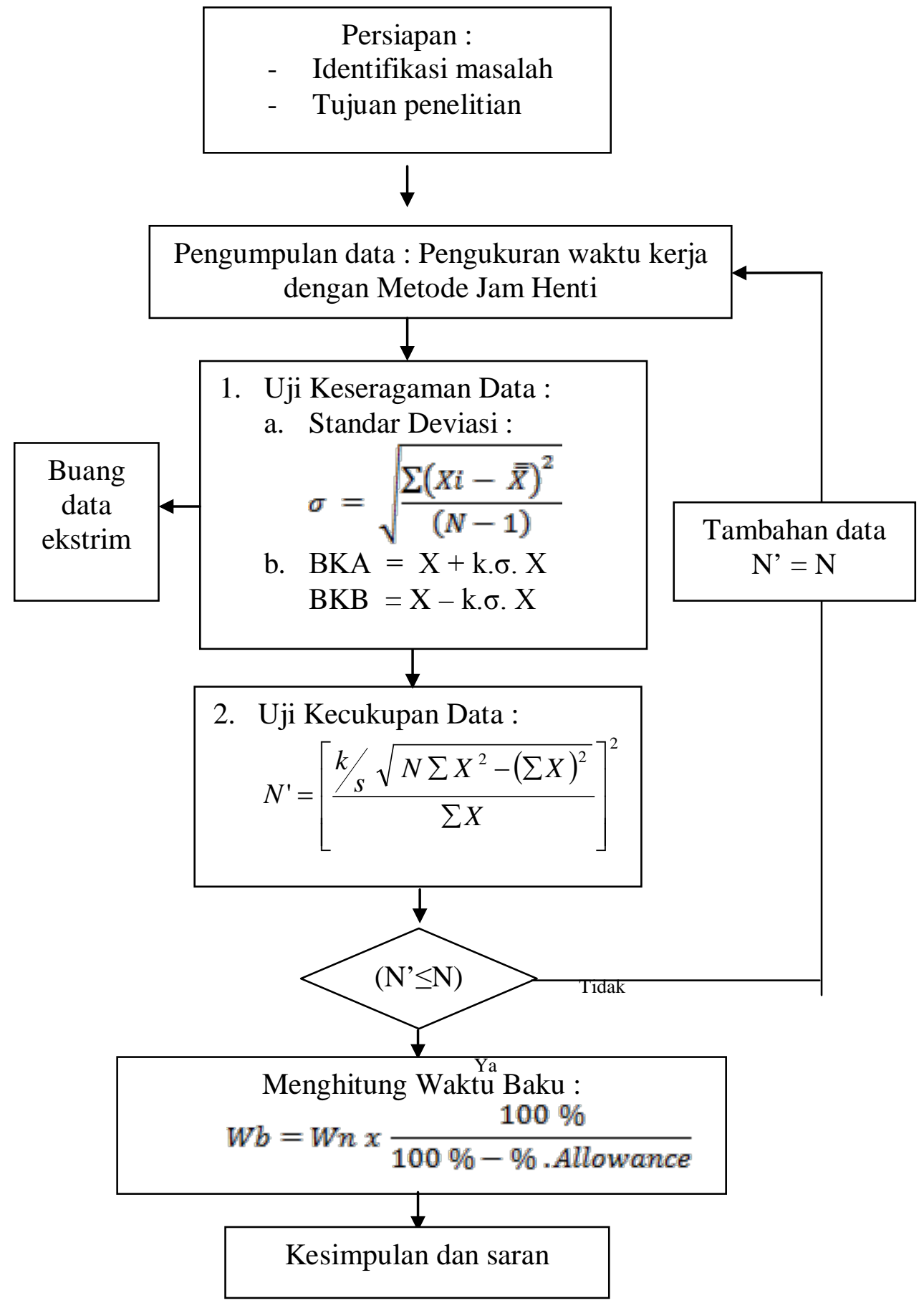

Gambar 2. Kerangka Pemecahan Masalah

\section{HASIL DAN PEMBAHASAN}

\section{A. Hasil}

Dalam melakukan pengukuran kerja di pilih tenaga yang mempunyai kompetensi (kemampuan dan keterampilan) normal, bukan yang mempunyai kompetensi tinggi ( diatas mormal ) agar waktu baku yang akan diterapkan mampu diikuti oleh rata-rata operator yang ada. Dalam penelitian ini setiap stasiun kerja dipilih satu operator. Adapun hasil pengamatannya dalam pengumpulan data ditunjukkan seperti tabel 1. 


\section{Uji Keseragaman Data}

Uji keseragaman data perlu dilakukan untuk mengetahui apakah data yang diperoleh sudah seragam atau belum. Langkah-langkah dalam uji keseragaman data adalah sebagai berikut :

Tabel 2. Lembar Pengamatan

\begin{tabular}{|c|c|c|c|c|c|c|c|}
\hline \multirow{4}{*}{\multicolumn{2}{|c|}{$\begin{array}{l}\text { Stasiun Kerja I } \\
\text { Produk } \\
\text { Jam Kerja } \\
\text { Tanggal dibuat }\end{array}$}} & \multirow{2}{*}{\multicolumn{3}{|c|}{$\begin{array}{l}\text { : Pengukusan } \\
\text { : Kerupuk Rambak Ikan Laut }\end{array}$}} & \multicolumn{3}{|c|}{ Nama KUBE : "Sari Enak" } \\
\hline & & & & & \multirow[t]{2}{*}{ Alamat } & \multicolumn{2}{|c|}{ : Wotgaleh Rt 02 RW IV } \\
\hline & & \multicolumn{3}{|c|}{ : 12 Jam / hari } & & \multicolumn{2}{|c|}{ Sukoharjo } \\
\hline & & $12 \mathrm{M}$ & uni 2013 & & Dibuat oleh & \multicolumn{2}{|c|}{ : Darsini } \\
\hline \multirow{2}{*}{$\begin{array}{l}\text { Sub } \\
\text { Grup }\end{array}$} & \multicolumn{5}{|c|}{ Waktu Pengamatan (menit) } & \multirow[b]{2}{*}{ ab total } & \multirow[b]{2}{*}{ Rata-rata } \\
\hline & 1 & 2 & 3 & 4 & 5 & & \\
\hline 1 & 31 & 31 & 30 & 30 & 31 & 152 & 30.4 \\
\hline 2 & 31 & 30 & 30 & 31 & 31 & 153 & 30.6 \\
\hline 3 & 31 & 29 & 31 & 30 & 28 & 149 & 29.8 \\
\hline 4 & 30 & 30 & 31 & 30 & 30 & 151 & 30.2 \\
\hline \multicolumn{5}{|c|}{$\left(\Sigma X^{2}\right) 18374$} & \multicolumn{2}{|c|}{$\Sigma X=606$} & $\sum \bar{X}=121,2$ \\
\hline
\end{tabular}

Untuk menguji keseragaman data di atas maka langkah perhitungannya sebagai berikut :

a. Harga rata-rata dari rata-rata sub grup

$$
\begin{aligned}
\overline{\bar{x}} & =\frac{\sum \bar{X}}{k} \\
& =\frac{121,2}{4}=30,3
\end{aligned}
$$

b. Standar deviasi

$$
\begin{aligned}
\sigma & =\sqrt{\frac{\sum(X i-\bar{X})^{2}}{(N-1)}} \\
& =\sqrt{\frac{\sum(30-31)^{2}+(30-31)^{2}+(30-31)^{2}+\cdots \cdots(30-31)^{2}+(30-28)^{2}+(30-30)^{2}}{20-1}} \\
& =\sqrt{\frac{12,2}{19}}=\sqrt{0,642}=0,80
\end{aligned}
$$


Tabel 1. Pengumpulan data

$\begin{array}{ll}\text { Jumlah Stasiun Kerja } & : 6 \text { (Enam) } \\ \text { Produk } & : \text { Kerupuk Rambak Ikan Laut } \\ \text { Jam Kerja } & : \text { 12 Jam / hari } \\ \text { Tanggal dibuat } & : \text { 15 Juni } 2013\end{array}$
Nama Perusahaan : KUBE "Sari Enak"
Alamat : Wotgaleh RT 02 RW IV
Sukoharjo
Dibuat oleh : Darsini

: 15 Juni 2013

\begin{tabular}{|c|c|c|c|c|c|c|c|c|c|c|c|c|c|c|c|c|c|c|c|c|c|c|c|c|}
\hline \multirow{2}{*}{ No } & \multirow{2}{*}{$\begin{array}{l}\text { Stasiun } \\
\text { Kerja }\end{array}$} & \multirow{2}{*}{ Jenis Kegiatan } & \multicolumn{20}{|c|}{ Waktu Pengukuran ( Menit) } & \multirow{2}{*}{$\mathrm{Jml}$} & \multirow{2}{*}{$\begin{array}{l}\text { Rata- } \\
\text { rata }\end{array}$} \\
\hline & & & 1 & 2 & 3 & 4 & 5 & 6 & 7 & 8 & 9 & 10 & 11 & 12 & 13 & 14 & 15 & 16 & 17 & 18 & 19 & 20 & & \\
\hline 1 & I & Pengukusan & 31 & 31 & 31 & 30 & 31 & 30 & 29 & 30 & 30 & 30 & 31 & 31 & 30 & 31 & 30 & 30 & 31 & 31 & 28 & 30 & 606 & 30.30 \\
\hline 2 & II & Pemotongan/Pengirisan & 58 & 59 & 58 & 58 & 58 & 58 & 58 & 58 & 57 & 60 & 58 & 58 & 58 & 58 & 60 & 58 & 59 & 58 & 57 & 58 & 1164 & 58.20 \\
\hline 3 & III & Pencampuran Bumbu & 6 & 5 & 5 & 5 & 6 & 6 & 6 & 5 & 5 & 4 & 5 & 6 & 5 & 7 & 6 & 5 & 5 & 4 & 5 & 5 & 106 & 5.30 \\
\hline 4 & IV & $\begin{array}{l}\text { Pengeringan/ } \\
\text { Penjemuran }\end{array}$ & 120 & 120 & 120 & 118 & 120 & 120 & 118 & 120 & 120 & 120 & 120 & 120 & 120 & 120 & 118 & 120 & 120 & 120 & 120 & 120 & 2394 & 119.70 \\
\hline 5 & $\mathrm{~V}$ & Penggorengan & 15 & 14 & 15 & 15 & 15 & 15 & 14 & 15 & 15 & 15 & 15 & 15 & 15 & 14 & 15 & 15 & 15 & 15 & 15 & 15 & 297 & 14.85 \\
\hline 6 & VI & Pengemasan & 40 & 40 & 40 & 41 & 41 & 40 & 40 & 40 & 40 & 41 & 40 & 40 & 40 & 40 & 40 & 41 & 41 & 40 & 40 & 41 & 806 & 40.30 \\
\hline
\end{tabular}


a. Standart deviasi dari harga rata-rata sub group

$$
\begin{aligned}
\sigma \bar{x} & =\frac{\sigma}{\sqrt{n}} \\
& =\frac{0,80}{\sqrt{5}}=0,36
\end{aligned}
$$

b. Batas Kontrol

$$
\begin{aligned}
& \mathrm{BKA}=\overline{\bar{X}}+3 \cdot \sigma \bar{X} \\
& =30,3+3(0,36) \\
& =31,38 \\
& \mathrm{BKB}=\overline{\bar{X}}-3 \cdot \sigma \bar{X} \\
& =30,3-3(0,36) \\
& =29,22
\end{aligned}
$$

\section{Tes Keseragaman Data}

Tingkat kepercayaan $=95 \%$, maka nilai $\mathrm{k}=2$

Derajat ketelitian (s) $=5 \%$

$$
\begin{aligned}
N^{\prime} & =\left[\frac{k / s \sqrt{N \sum X^{2}-\left(\sum X\right)^{2}}}{\sum X}\right]^{2} \\
& =\left[\frac{40 \sqrt{20(18374)-(367236)}}{606}\right]^{2} \\
& =\left[\frac{40 x 15,62}{606}\right]^{2}=1,06
\end{aligned}
$$

Karena N' $<$ N maka data di atas cukup

\section{Penghitungan Waktu Normal}

Faktor penyesuaian :
a. Ketrampilan (skill) $=\mathrm{B} 2=0.08$
b. Usaha (effort) = $\mathrm{C} 1=0.05$
c. Kondisi (condition) $=\mathrm{C}=0.02$
d. Keajegan (consistency) $=\mathrm{C}=0.01$ Jumlah $=0.16$
Ws $=\overline{\bar{X}}$
Faktor penyesuaian di atas normal, sehingga
$\mathrm{P}=(1+0.16)=1.16$
$\mathrm{Wn}=\overline{\bar{X}} x P$

$$
=30.30 \times 1.16=35.15 \text { menit }
$$

\section{Penghitungan Waktu Baku (Standart)}

Faktor Kelonggaran (allowance) :
a. Kebutuhan pribadi (personal needs) $=5 \%=0.05$
b. Melepas lelah (fatique) $\quad=0 \%=0.00$
c. Keterlambatan (delay) $=2 \%=0.02$
$=7 \%=0.07$
Jumlah $W b=W n \times \frac{100 \%}{100 \%-\% \cdot \text { Allowance }}$ 


$$
\begin{aligned}
W b & =35.15 \times \frac{100 \%}{100 \%-7 \%} \\
& =35.15 \times 1.0007 \quad=35,17 \text { Menit }
\end{aligned}
$$

Jadi waktu baku untuk pekerjaan pengadukan satu tenaga kerja yang menangani adalah 35,17 menit setiap kali pengolahan.

Dengan cara yang sama, maka untuk hasil perhitungan uji keseragaman dan kecukupan semua data dikatakan seragam dan data telah cukup. Sedangkan juga waktu normal dan waktu baku (standart) pada setiap stasiun kerja hasilnya seperti pada tabel 3.

\section{B. Pembahasan}

Berdasarkan pengumpulan data kemudian dilakukan pengolahan data di atas, dapat dianalisa sebagai berikut :

1. Dalam proses produksi pembuatan rambak/kerupuk ikan laut di KUBE "Sari Enak" di Wotgaleh Sukoharjo sampai produk akhir melalui enam stasiun kerja yang tujuannya adalah untuk mempermudah dalam pengukuran waktu kerja.

2. Pengukuran waktu kerja dilakukan sebanyak 20 kali dengan cara pengukuran langsung menggunakan stop watch dari masing-masing stasiun kerja atau urutan proses produksinya.

3. Dari pengamatan yang telah dilakukan langsung di lokasi / KUBE "Sari Enak" diperoleh total waktu standar dari 6 stasiun kerja adalah 306,58 menit. Dan setiap kali pengamatan yang dilakukan sebanyak 20 kali setiap memasak $3 \mathrm{~kg}$. Waktu yang dibutuhkan untuk proses produksi dari stasiun kerja I sampai stasiun kerja 6 dengan memasak $60 \mathrm{~kg}$ rambak/kerupuk ikan laut membutuhkan waktu standar sebesar = 306,58 menit atau 5.11 jam. 
Tabel 3.

Perhitungan Waktu Normal dan Waktu Baku (Standart)

\begin{tabular}{|c|c|c|c|c|c|c|c|c|c|c|c|c|c|c|c|}
\hline \multirow{3}{*}{ No } & \multirow{3}{*}{$\begin{array}{l}\text { Stasiun } \\
\text { kerja }\end{array}$} & \multirow{3}{*}{ Jenis Kegiatan } & \multirow{3}{*}{$\mathrm{N}$} & \multicolumn{7}{|c|}{ Waktu Normal } & \multicolumn{5}{|c|}{ Waktu Standart } \\
\hline & & & & \multirow{2}{*}{$\mathrm{X}$} & \multicolumn{5}{|c|}{ Penyesuaian (P) } & \multirow{2}{*}{$\begin{array}{c}\text { Wn } \\
\text { (Menit) }\end{array}$} & \multicolumn{4}{|c|}{ Kelonggaran (Allowance) } & \multirow{2}{*}{$\mathrm{Wb}$} \\
\hline & & & & & Skill & Effort & Condition & $\begin{array}{l}\text { Consis } \\
\text { - tency } \\
\end{array}$ & $\Sigma$ & & $\begin{array}{c}\text { Keb. } \\
\text { Pribadi }\end{array}$ & $\begin{array}{l}\text { melepa } \\
\text { s lelah }\end{array}$ & $\begin{array}{c}\text { Keter- } \\
\text { lambatan }\end{array}$ & $\Sigma$ & \\
\hline 1 & I & Pengukusan & 20 & 30.30 & 0.08 & 0.05 & 0.02 & 0.01 & 0.16 & 35.15 & 0.05 & 0.00 & 0.02 & 0.07 & 35.17 \\
\hline 2 & II & $\begin{array}{l}\text { Pemotongan/ } \\
\text { Pengirisan }\end{array}$ & 20 & 58.20 & 0.08 & 0.05 & 0.02 & 0.01 & 0.16 & 67.51 & 0.02 & 0.00 & 0.02 & 0.04 & 67.54 \\
\hline 3 & III & Pencampuran Bumbu & 20 & 5.30 & 0.08 & 0.05 & 0.02 & 0.01 & 0.16 & 6.15 & 0.05 & 0.00 & 0.02 & 0.07 & 6.15 \\
\hline 4 & IV & $\begin{array}{l}\text { Pengeringan/ } \\
\text { Penjemuran }\end{array}$ & 20 & $\begin{array}{c}119.7 \\
0 \\
\end{array}$ & 0.08 & 0.02 & 0.02 & 0.00 & 0.12 & 134.06 & 0.00 & 0.00 & 0.02 & 0.02 & 134.09 \\
\hline 5 & $\mathrm{~V}$ & Penggorengan & 20 & 14.85 & 0.08 & 0.05 & 0.02 & 0.01 & 0.16 & 17.23 & 0.00 & 0.00 & 0.02 & 0.02 & 17.23 \\
\hline 6 & VI & Pengemasan & 20 & 40.30 & 0.06 & 0.05 & 0.02 & 0.02 & 0.15 & 46.35 & 0.06 & 0.02 & 0.02 & 0.10 & 46.39 \\
\hline & & \multicolumn{8}{|c|}{ Waktu Normal } & 306.44 & \multicolumn{4}{|c|}{ Waktu baku (standart) } & 306.58 \\
\hline
\end{tabular}




\section{KESIMPULAN DAN SARAN}

Dari hasil pengamatan, pengolahan data dan analisa yang telah dipaparkan di muka dapat di simpulkan bahwa :

1. Dari hasil perhitungan keseragaman data dan kecukupan data yang terdiri enam stasiun kerja yang masing-masing diambil sebanyak 20 (dua puluh) data. Dari perhitungan diperoleh hasil bahwa data seragam dan cukup.

2. Dari perhitungan telah diperoleh waktu normal dan waktu baku (standart) tiap stasiun kerja dalam proses produksi pembuatan kerupuk rambak ikan laut. Secara komulatif waktu normal 306,44 menit dan waktu baku (standart) 306,58 menit. Jadi waktu yang dibutuhkan untuk proses pembuatan kerupuk rambak ikan lain dalam 1 periode pembuatan $(60 \mathrm{~kg})$ membutuhkan waktu 306,58 menit. Jadi selama satu hari kerja misalnya 8 jam, untuk istirahat 1 jam, maka satu hari dapat memproduksi kerupuk ikan laut sebanyak : $=\frac{420 \text { menit }}{306,58 \text { menit }}=1.4$ kali. Dalam satu hari dapat memproduksi 1 sampai dengan 2 kali proses produksi/pemasakan.

\section{DAFTAR PUSTAKA}

[1] Assauri Sofyan. 1984. Teknik dan Metode Peramalan. Penerbit BPFE UI, Jakarta

[2] Sutalaksana , I Z, 1980. Teknik Tata Cara Kerja, Edisi Ke-2. Departemen Teknik Industri ITB. Bandung

[3] Wignyosoebroto, Sritomo, 1989, Teknik Tata Cara, dan Pengukuran Kerja, Laboratorium Ergonomi dan Tata Cara. Teknik Industri ITS, Surabaya 